\title{
Variations in the IBD5 locus confer the risk of inflammatory bowel disease in a Manitoban Caucasian Cohort
}

\author{
Alejandra Serrano León ${ }^{1}$, Charles N Bernstein ${ }^{2,3}$, Hani El-Gabalawy ${ }^{3}$ and Peter Eck ${ }^{*}$ \\ ${ }^{1}$ Department of Food and Human Nutritional Sciences, University of Manitoba, MB R3T 2N2, Canada \\ ${ }^{2}$ University of Manitoba IBD Clinical and Research Centre, Canada \\ ${ }^{3}$ Department of Internal Medicine, University of Manitoba, MB R3T 2N2, Canada
}

\begin{abstract}
Background: Crohn's disease (CD) and ulcerative colitis (UC) are two distinct manifestations of inflammatory bowel disease (IBD). Polymorphisms in the $S L C 22 A 4$ and $S L C 22 A 5$ genes were associated within the IBD5 locus, but their contribution to the pathology remains unclear.

Objective: This study investigated the association to IBD of common and rare variations within the SLC22A4 and SLC22A5 genes in the Manitoban IBD cohort.

Design: DNA samples from $160 \mathrm{CD}$ patients, 149 UC patients and 142 age and gender matched healthy controls were genotyped for selected single nucleotide polymorphisms (SNPs) tagging both genes.

Results: The $S L C 22 A 5$ genotypes rs11739135-CC and rs17622208-AA associated with increased susceptibility for CD (OR=7.84, 95\% CI 2.84-21.6, p=0.000; $\mathrm{OR}=2.26,95 \%$ CI 1.14-4.44, $\mathrm{p}=0.019$, respectively). Moreover, rs11739135-CC homozygosity was associated with UC (OR=4.18, 95\% CI 1.48-11.78, $\mathrm{p}=0.007)$. None of the common polymorphisms tested in SLC22A4 were associated with either CD or UC. Two rarer genotypes in SLC22A4, rs11568500-A and rs11568510-G, were not detected.
\end{abstract}

Conclusion: Variations in the proximal part of the $S L C 22 A 5$ gene associated with IBD distinct from other variations in the IBD5 locus, including those of $S L C 22 A 4$. Therefore, disturbed carnitine transport might be involved in IBD etiology in a small percentage of individuals.

\section{Introduction}

Crohn's disease (CD) and ulcerative colitis (UC) are the main manifestations of inflammatory bowel disease (IBD). The disease arises from a complex interplay of environmental, host immune dysregulations and genetic factors [1].

The IBD5 locus in chromosome $5 q 31$ was first identified to confer $\mathrm{CD}$ risk in a Canadian population [1], and in further analysis a $250 \mathrm{~kb}$ IBD5 haplotype was associated to CD [2]. Both, the susceptibility to $\mathrm{CD}$ and UC were located to IBD5 in a German cohort [3]. The IBD5 genomic region contains immune related genes: interleukin-4 (IL4), IL13, IL5 and interferon regulatory factor-1 (IRF1), but it also contains two organic cation/carnitine transporters SLC22A4 and SLC22A5.

It was suggested by Peltekova et al. [4] that the non-synonymous single nucleotide polymorphism (SNP) rs1050152, located in SLC22A4 exon 9, and the SNP rs2631367, located in the SLC22A5 5'UTR, were true functional polymorphisms determining $C D$ risk in the $I B D 5$ locus in a haplotype-independent manner. The associations in the IBD5 locus have been replicated [5-12], but not independently from linked SNPs in the IBD5 haplotype.

Moreover, the IBD5 locus including SLC22A4 and SLC22A5 has been associated with UC $[3,11,13,14]$, but associations were not replicated in a Canadian [7], a Belgian [15], and other cohorts of Asian ancestry $[16,17]$. Meta-analyses suggest that SNPs rs12521868
(IGR2096), rs11739135 (IGR2198) and rs17622208 (IGR2230) tag the IBD5 locus and are in linkage with SLC22A4-rs1050152 and SLC22A5rs2631367 and associated with CD and UC in Caucasian cohorts $[18,19]$.

Taken together, there is possible evidence that functional genetic variations in the SLC22A4 and SLC22A5 genes, encoding organic cation transporter proteins OCTN1 (SLC22A4) and OCTN2 (SLC22A5), contribute to IBD risk. However, it remains undetermined if the variants act independent, or together with each other or nearby variations in immunity-related genes. Therefore, we investigated associations of both common and rarer variations in the SLC22A4 gene and common variations in the SLC22A5 gene in a cohort of Caucasian individuals in Manitoba, Canada. We included rarer variations in SLC22A4 known to abrogate the protein's function since we hypothesize that they would be observed in the disease cohort if elimination of the gene would have a role in disease development.

*Correspondence to: Peter Eck, University of Manitoba, Department of Human Nutritional Sciences, W569 Duff Roblin Building, 190 Dysart Road, Winnipeg MB R3T2N2, Canada, Tel: +1-204 291 2917; E-mail: peter.eck@ad.umanitoba.ca

Key words: SLC22A4, SLC22A5, IBD5, polymorphisms, inflammatory bowel disease, Crohn's Disease, Ulcerative Colitis

Received: July 14, 2018; Accepted: July 26, 2018; Published: July 31, 2018 


\section{Subjects and methods}

\section{Study population}

The study population included 311 IBD patients from the Manitoba Inflammatory Bowel Disease Cohort Study that has been described previously [20]. We included Caucasian age and gender matched CD $(\mathrm{n}=162)$, and UC $(\mathrm{n}=149)$ patients as well as healthy controls $(\mathrm{n}=142)$. The diagnosis and classification of $\mathrm{CD}$ and UC was determined based on radiologic, endoscopic and histological data as established based on the Montreal classification [21]. The phenotypic characteristics of CD and UC patients are shown in Table 1.

\section{Genotyping}

All protocols were approved by the University of Manitoba Research Ethics Committee. Genomic DNA was isolated from peripheral blood as described previously [22]. The common SNPs rs1050152 (SLC22A4), rs17622208 (SLC22A5), rs11739135, (3' of SLC22A5) and rs12521868 (C5orf56), previous reported to tag the IBD5 locus and the rare functional SNPs rs11568500, rs11568510 in SLC22A4 were genotyped by PCR-RFLP analysis.

The PCR amplifications were performed in the NEB Taq Polymerase 5X Master Mix (New England BioLabs) following the manufacturer's protocol under the following cycling conditions and the primers listed in Table 2, initial denaturation at $95^{\circ} \mathrm{C}$ for 30 s, followed by 35 cycles of denaturation at $95^{\circ} \mathrm{C}$ for $15 \mathrm{~s}$, annealing at $50^{\circ} \mathrm{C}$ for $15 \mathrm{~s}$, extension at $68^{\circ} \mathrm{C}$ for $2 \mathrm{~min}$ and final extension at $68^{\circ} \mathrm{C}$ for $5 \mathrm{~min}$.

The amplicons were digested by allele-specific restriction endonucleases (New England BioLabs) according to manufacturer's protocols as listed in Table 2 . Restriction patterns were analyzed by gel electrophoresis in a $2 \%$ Ultrapure agarose gel (Invitrogen) after ethidium bromide staining under UV light (Gel Doc, BIO-RAD). Amplicons of known genotype for every SNP were sub cloned using polyAA cloning (TOPO ${ }^{\circ} \mathrm{TA}$ Cloning, Invitrogen) and used as positive and negative controls for further PCR and restriction analysis.

\section{Statistical Analyses}

SNPs were tested for Hardy-Weinberg equilibrium. The casecontrol associations of genotype and allele frequencies of each SNP were tested using binary logistic regression. Odds ratios (OR) were calculated with $95 \%$ confidence interval $(\mathrm{CI})$ using $2 \times 2$ contingency tables and $\mathrm{x}^{2}$ test. The analysis was carried out using SPSS 18.0. The linkage disequilibrium (LD) and haplotype analysis in the $I B D 5$ region was performed with Haploview 4.2 [23].

Table 1. Phenotypic characteristics of the Caucasian IBD cohort

\begin{tabular}{|c|c|c|}
\hline & $\begin{array}{l}\text { Crohn's Disease } \\
\text { cohort }(n=154)\end{array}$ & $\begin{array}{l}\text { Ulcerative Colitis } \\
\text { cohort }(n=143)\end{array}$ \\
\hline \multicolumn{3}{|c|}{ Gender } \\
\hline Female & $91(59.1 \%)$ & $87(60.8 \%)$ \\
\hline Male & $63(40.9 \%)$ & $56(39.2 \%)$ \\
\hline \multicolumn{3}{|c|}{ Age at diagnosis } \\
\hline $\mathrm{A} 1(<16$ years $)$ & $14(9.1 \%)$ & $12(8.4 \%)$ \\
\hline A2 (16-40 years) & $101(65.6 \%)$ & $78(54.5 \%)$ \\
\hline A3 (>40 years) & $39(25.3 \%)$ & $53(37.1 \%)$ \\
\hline \multicolumn{3}{|c|}{ Location } \\
\hline L1 (Ileal) & $69(44.8 \%)$ & - \\
\hline L2 (Colonic) & $33(21.4 \%)$ & - \\
\hline L3 (Ileocolonic) & $51(33.1 \%)$ & - \\
\hline L4 (isolated upper disease) & $1(0.6 \%)$ & - \\
\hline E1 (UP limited to rectum) & - & $10(7 \%)$ \\
\hline E2 (Left sided, distal) & - & $66(46.2 \%)$ \\
\hline E3 (extensive, pancolitis) & - & $67(46.9 \%)$ \\
\hline \multicolumn{3}{|c|}{ Behaviour } \\
\hline B1(Inflammatory) & $66(42.9 \%)$ & - \\
\hline B2 (Stricturing) & $51(33.1 \%)$ & - \\
\hline B3 (Penetrating/fistulizing) & $37(24 \%)$ & - \\
\hline
\end{tabular}

Table 2. Primer sequence, restriction enzymes and cutting pattern for RFLP genotyping

\begin{tabular}{|c|c|c|c|c|}
\hline Gene & dbSNP & Primer Sequence $5^{\prime}-3^{\prime}$ & Endonuclease & Cutting pattern (bp) \\
\hline \multirow{2}{*}{ SLC22A4 } & \multirow{2}{*}{ rs1050152 } & Forward: TTGATGTTCTTATGTCCCGG & \multirow{2}{*}{ MnlI } & $\mathrm{C}: 212+97 \mathrm{bp}$ \\
\hline & & Reverse: TGTGCCCAGCCAACAATATG & & T: 309 bp \\
\hline \multirow{2}{*}{ SLC22A4 } & \multirow{2}{*}{ rs 11568500} & Forward: ACCTTGGCAACCTACACATC & \multirow{2}{*}{ Sau96I } & $\mathrm{G}: 168 \mathrm{bp}$ \\
\hline & & Reverse: TTCAGAGGGTTAGAGGGA & & A:85bp \\
\hline \multirow{2}{*}{ SLC22A4 } & \multirow{2}{*}{ rs 11568510} & Forward: TTCCTTGGCAGTGGAATCTG & \multirow{2}{*}{ BspmI } & $\mathrm{A}: 312 \mathrm{bp}$ \\
\hline & & Reverse: GAACAAAAGTGTGTCCAGGT & & G:203+109 bp \\
\hline \multirow{2}{*}{ IGR2096 } & \multirow{2}{*}{ rs 12521868} & Forward: ATCCTCCATGCTACTGCT & \multirow{2}{*}{ DraI } & G: 308 bp \\
\hline & & Reverse: TGGTGTAGCCAGAGTAGA & & $\mathrm{T}: 159+149 \mathrm{bp}$ \\
\hline \multirow{2}{*}{ IGR2198 } & \multirow{2}{*}{ rs11739135 } & Forward: ACTGGCTCTTTACCTGGGAA & \multirow{2}{*}{ SfaNI } & G: 369 bp \\
\hline & & Reverse: AACTAGTCCCAACGAGATGA & & $\mathrm{C}: 245+124 \mathrm{bp}$ \\
\hline \multirow{2}{*}{$\begin{array}{l}\text { SLC22A5 } \\
\text { IGR2230 }\end{array}$} & \multirow{2}{*}{ rs17622208 } & Forward: AGGTCTATTCCCAGGGAA & \multirow{2}{*}{ DdeI } & G: $164+119 b p$ \\
\hline & & Reverse: ACTCAGAAGCTGTCCATC & & A:283 bp \\
\hline
\end{tabular}




\section{Results}

\section{Common SNPs and haplotypes in the SLC22A5 gene are associated with Crohn's Disease}

Two SNPs in the SLC22A5 gene associated with the risk of CD, and as a likely consequence several haplotypes inferred of these SNPs associated also with CD (Table 3). Specifically, carriers of the SNP rs 17622208 A-allele showed an $40 \%$ elevated risk for $\mathrm{CD}(\mathrm{OR}=1.4 ; 95 \%$ CI 1.01-1.92; $\mathrm{p}=0.04)$, consistently elevating the risk for the combined genotypes AA/GA (OR=2.76; 95\% CI 1.54-4.95; p=0.001) (Table 3).
Similarly, carriers of the SNP rs11739135 C-allele showed an $80 \%$ elevated risk for $\mathrm{CD}(\mathrm{OR}=1.8 ; 95 \% \mathrm{CI} 1.28-2.5 ; \mathrm{p}=0.000)$. Significantly, the disease risk for rs11739135-CC homozygotes is strongly elevated with an OR of 7.84 (95\% CI 2.84-21.6; $\mathrm{p}=0.000)$ through the fact that $20.6 \%$ of CD patients, but only $3.5 \%$ of healthy controls carried that genotype (Table 3).

Neither of the other two common tag-SNPs in the IBD5 locus associated to $\mathrm{CD}$, but the haplotype TACT [inferred from SNPs rs1050152, rs17622208, rs11739135, and rs12521868, respectively]

Table 3. Genotype and allele frequencies in Crohn's disease and control subjects

\begin{tabular}{|c|c|c|c|c|}
\hline & $\begin{array}{c}\text { Crohn's disease } \\
\quad(n=160)\end{array}$ & Controls $(n=142)$ & OR $(95 \%$ CI) & $p$ \\
\hline \multicolumn{5}{|c|}{ SLC22A4 rs11568510 } \\
\hline \multicolumn{5}{|l|}{ Exon 2} \\
\hline AA & $160(100 \%)$ & $142(100 \%)$ & ND & \\
\hline GG & $0(0 \%)$ & $0(0 \%)$ & ND & \\
\hline \multicolumn{5}{|c|}{ SLC22A4 rs11568500 } \\
\hline \multicolumn{5}{|c|}{ Exon 3} \\
\hline GG & $160(100 \%)$ & $142(100 \%)$ & ND & \\
\hline AA & $0(0 \%)$ & $0(0 \%)$ & ND & \\
\hline \multicolumn{5}{|c|}{ SLC22A4 rs1050152 } \\
\hline Exon 9 & $n=160$ & $n=142$ & & \\
\hline $\mathrm{CC}$ & $42(26.3 \%)$ & $51(35.9 \%)$ & Ref. & \\
\hline $\mathrm{CT}$ & $79(49.4 \%)$ & $61(43 \%)$ & $1.57(0.93-2.66)$ & 0.09 \\
\hline TT & $39(24.4 \%)$ & $30(21.2 \%)$ & $1.58(0.84-2.95)$ & 0.15 \\
\hline $\mathrm{CT}+\mathrm{TT}$ & $118(73.8 \%)$ & $91(64.1 \%)$ & $1.60(0.96-2.57)$ & 0.07 \\
\hline $\mathrm{C}$ allele & $163(51 \%)$ & $163(57 \%)$ & $0.77(0.56-1.06)$ & 0.11 \\
\hline $\mathrm{T}$ allele & $157(49 \%)$ & $121(43 \%)$ & $1.3(0-94-1.8)$ & 0.11 \\
\hline \multicolumn{5}{|c|}{$S L C 22 A 5$ rs17622208 } \\
\hline Intron 2 & $n=159$ & $n=142$ & & \\
\hline GG & $21(13.2 \%)$ & $42(29.6 \%)$ & Ref. & \\
\hline GA & $94(59.1 \%)$ & $61(43 \%)$ & $3.08(1.67-5.70)$ & 0.000 \\
\hline AA & $44(27.7 \%)$ & $39(27.5 \%)$ & $2.26(1.14-4.44)$ & 0.019 \\
\hline $\mathrm{GA}+\mathrm{AA}$ & $138(86.8 \%)$ & $100(70.4 \%)$ & $2.76(1.54-4.95)$ & 0.001 \\
\hline G allele & $136(43 \%)$ & $145(51 \%)$ & $0.72(0.52-0.98)$ & 0.04 \\
\hline A allele & $182(57 \%)$ & $139(49 \%)$ & $1.4(1.01-1.92)$ & 0.04 \\
\hline \multicolumn{5}{|c|}{$S L C 22 A 5$ rs11739135 } \\
\hline Intergenic near $3^{\prime}$ & $n=160$ & $n=142$ & & \\
\hline GG & $48(30 \%)$ & $57(40.1 \%)$ & Ref. & \\
\hline GC & $79(49.4 \%)$ & $80(56.3 \%)$ & $1.17(0.72-1.92)$ & 0.53 \\
\hline $\mathrm{CC}$ & $33(20.6 \%)$ & $5(3.5 \%)$ & $7.84(2.84-21.6)$ & 0.000 \\
\hline $\mathrm{GC}+\mathrm{CC}$ & $112(70 \%)$ & $85(59.8 \%)$ & $1.56(0.97-2.52)$ & 0.06 \\
\hline G allele & $175(55 \%)$ & $194(68 \%)$ & $0.56(0.40-0.78)$ & 0.000 \\
\hline $\mathrm{C}$ allele & $145(45 \%)$ & $90(32 \%)$ & $1.8(1.28-2.5)$ & 0.000 \\
\hline \multicolumn{5}{|c|}{ C5orf56 rs12521868 } \\
\hline Intron 2 & $n=159$ & $n=142$ & & \\
\hline GG & $43(27 \%)$ & $53(37.3 \%)$ & Ref. & \\
\hline GT & $83(52.2 \%)$ & $62(43.7 \%)$ & $1.65(0.98-2.77)$ & 0.06 \\
\hline TT & $33(20.8 \%)$ & $27(19 \%)$ & $1.51(0.78-2.88)$ & 0.22 \\
\hline $\mathrm{GT}+\mathrm{TT}$ & $116(72.9 \%)$ & $89(62.7 \%)$ & $1.61(0.98-2.62)$ & 0.06 \\
\hline G allele & $169(53 \%)$ & $168(59 \%)$ & $0.78(0.57-1.08)$ & 0.13 \\
\hline T allele & $149(47 \%)$ & $116(41 \%)$ & $1.28(0.92-1.76)$ & 0.13 \\
\hline \multicolumn{5}{|c|}{ IBD5 Haplotype ${ }^{a}$} \\
\hline CGGG & $59(36.4 \%)$ & $71(50 \%)$ & $0.55(0.33-0.93)$ & 0.02 \\
\hline TACT & $63(38.8 \%)$ & $42(29.8 \%)$ & $1.8(1.07-3.04)$ & 0.02 \\
\hline CAGG & $21(12.9 \%$ & $9(6.3 \%)$ & $2.8(1.87-3.84)$ & 0.00 \\
\hline TGCT & $7(4.2 \%)$ & $1(0.3 \%)$ & $4.8(2.97-6.45)$ & 0.00 \\
\hline TAGT & $6(3.2 \%)$ & $14(9.7 \%)$ & $0.45(0.33-0.65)$ & 0.00 \\
\hline
\end{tabular}

${ }^{a}$ Haplotypes were formed by the SNPs rs1050152, rs17622208, rs11739135, rs12521868, respectively. 
reflected an elevated risk for $\mathrm{CD}(\mathrm{OR}=1.8 ; 95 \% \mathrm{CI} 1.07-3.04 ; \mathrm{p}=0.02)$ Other haplotypes also associated with $\mathrm{CD}$, such as haplotype $\mathrm{CAGG}$, which was found in $12.9 \%$ of CD patients as compared to $6.3 \%$ in healthy controls $(\mathrm{p}=0.00)$. Moreover, haplotype TGCT was carried by $4.2 \%$ of $\mathrm{CD}$ patients compared to $0.3 \%$ in healthy controls $(\mathrm{p}=0.00)$. The haplotype CGGG conferred protection from CD ( $\mathrm{OR}=0.55 ; 95 \%$ CI 0.33-0.93; $\mathrm{p}=0.02$ ) (Table 3).

\section{CC-homozygosity for SNP rs11739135 in the SLC22A5 gene elevated the risk for Ulcerative Colitis}

SNP rs11739135-CC homozygotes showed an almost 3-fold elevated risk for UC $(\mathrm{OR}=4.18$; 95\% CI 1.48-11.78; $\mathrm{p}=0.07)$, due to overrepresentation in $14.8 \%$ of $\mathrm{CD}$ patients compared to $3.5 \%$ in healthy controls (Table 4). No other tested SNP or haplotype had an impact on the risk for UC.

\section{The rare genotypes rs11568500-A and rs11568510-G in the SLC22A4 gene were not present in the patient cohort}

The rare functional polymorphisms rs11568500-A and rs11568510-G in SLC22A4 were not present in the CD and UC patients or in the control groups (Tables 3,4). This Caucasian population carried only the homozygous ancestral genotype.

\section{Discussion}

None of the common SNPs in the IBD5 locus except in the SLC22A5 gene associated with IBD, where the alleles rs17622208-A and rs11739135-C elevated the risk for CD, and rs11739135-C for UC. This confers with previously reported associations for the SLC22A5 gene. However, does not replicate previous associations in the flanking genes SLC22A4 and C5orf56.

Table 4. Genotype and allele frequencies in ulcerative colitis and control subjects

\begin{tabular}{|c|c|c|c|c|}
\hline & $\begin{array}{c}\text { Ulcerative colitis } \\
\quad(n=149)\end{array}$ & $\begin{array}{l}\text { Controls } \\
(n=142)\end{array}$ & OR (95\% CI) & $p$ \\
\hline \multicolumn{5}{|c|}{ Exon 2} \\
\hline AA & $149(100 \%)$ & $142(100 \%)$ & ND & \\
\hline GG & $0(0 \%)$ & $0(0 \%)$ & ND & \\
\hline \multicolumn{5}{|c|}{$\begin{array}{l}\text { SLC22A4 rs11568500 } \\
\text { Exon } 3\end{array}$} \\
\hline GG & $149(100 \%)$ & $142(100 \%)$ & ND & \\
\hline AA & $0(0 \%)$ & $0(0 \%)$ & ND & \\
\hline \multicolumn{5}{|c|}{${ }_{\text {Exon } 9}{ }^{S L C 22 A 4 \mathrm{rs} 1050152}$} \\
\hline $\mathrm{CC}$ & $54(36.2 \%)$ & $51(35.9 \%)$ & Ref. & \\
\hline $\mathrm{CT}$ & $69(46.3 \%)$ & $61(43 \%)$ & $1.07(0.64-1.79)$ & 0.80 \\
\hline TT & $26(17.4 \%)$ & $30(21.2 \%)$ & $0.82(0.43-1.57)$ & 0.55 \\
\hline $\mathrm{CT}+\mathrm{TT}$ & $95(63.8 \%)$ & $91(64.1 \%)$ & $0.99(0.61-1.59)$ & 0.95 \\
\hline C allele & $177(59 \%)$ & $163(57 \%)$ & $1.09(0.78-1.51)$ & 0.62 \\
\hline T allele & $121(41 \%)$ & $121(43 \%)$ & $0.92(0.66-1.28)$ & 0.62 \\
\hline \multicolumn{5}{|c|}{$\begin{array}{l}\quad S L C 22 A 5 \mathrm{rs} 17622208 \\
\text { Intron } 2\end{array}$} \\
\hline GG & $44(29.5 \%)$ & $42(29.6 \%)$ & Ref. & \\
\hline GA & $76(51 \%)$ & $61(43 \%)$ & $1.19(0.69-2.04)$ & 0.53 \\
\hline AA & $29(19.5 \%)$ & $39(27.5 \%)$ & $0.71(0.37-1.35)$ & 0.29 \\
\hline $\mathrm{GA}+\mathrm{AA}$ & $105(70.5 \%)$ & $100(70.4 \%)$ & $1.00(0.61-1.66)$ & 0.99 \\
\hline $\mathrm{G}$ allele & $164(55 \%)$ & $145(51 \%)$ & $1.17(0.85-1.62)$ & 0.33 \\
\hline A allele & $134(45 \%)$ & $139(49 \%)$ & $0.85(0.61-1.18)$ & 0.33 \\
\hline \multicolumn{5}{|c|}{$\begin{array}{l}\text { SLC22A5 rs11739135 } \\
\text { Intergenic near 3, }\end{array}$} \\
\hline GG & $60(40.3 \%)$ & $57(40.1 \%)$ & Ref. & \\
\hline GC & $67(45 \%)$ & $80(56.3 \%)$ & $0.79(0.49-1.29)$ & 0.36 \\
\hline $\mathrm{CC}$ & $22(14.8 \%)$ & $5(3.5 \%)$ & $4.18(1.48-11.78)$ & 0.007 \\
\hline $\mathrm{GC}+\mathrm{CC}$ & $89(59.7 \%)$ & $85(59.8 \%)$ & $0.99(0.62-1.59)$ & 0.98 \\
\hline G allele & $187(63 \%)$ & $194(68 \%)$ & $0.78(0.55-1.10)$ & 0.15 \\
\hline $\mathrm{C}$ allele & $111(37 \%)$ & $90(32 \%)$ & $1.28(0.91-1.80)$ & 0.15 \\
\hline \multicolumn{5}{|c|}{$\begin{array}{l}\text { C5orf56 rs12521868 } \\
\text { Intron } 2\end{array}$} \\
\hline GG & $58(38.9 \%)$ & $53(37.3 \%)$ & Ref. & \\
\hline GT & $67(45 \%)$ & $62(43.7 \%)$ & $0.99(0.59-1.64)$ & 0.96 \\
\hline TT & $24(16.1 \%)$ & $27(19 \%)$ & $0.81(0.42-1.58)$ & 0.54 \\
\hline $\mathrm{GT}+\mathrm{TT}$ & $91(61.1 \%)$ & $89(62.7 \%)$ & $0.93(0.58-1.50)$ & 0.78 \\
\hline G allele & $183(61 \%)$ & $168(59 \%)$ & $1.10(0.78-1.53)$ & 0.58 \\
\hline T allele & $115(39 \%)$ & $116(41 \%)$ & $0.91(0.65-1.27)$ & 0.58 \\
\hline \multicolumn{5}{|c|}{ IBD5 Haplotype ${ }^{a}$} \\
\hline CGGG & $74(49.4 \%)$ & $72(50.2 \%)$ & $0.96(0.57-1.63)$ & 0.88 \\
\hline TACT & $46(30.9 \%)$ & $43(29.7 \%)$ & $1.04(0.61-1.76)$ & 0.88 \\
\hline
\end{tabular}

${ }^{a}$ Haplotypes were formed by the SNPs rs1050152, rs17622208, rs11739135, rs12521868. All SNPs conferred to the Hardy-Weinberg equilibrium. 
The common nonsynonymous SNP rs1050152-T in SLC22A4 which encodes amino acid 503F was previously reported by Peltekova et al. [4] to be present in $53 \%$ of CD cases but only $23 \%$ of healthy control, indicating a strong disease association, and these findings had been replicated in different cohorts $[9,24,25]$. However, this association could not be replicated by others $(5,6,14,15,26)$. For example, Waller et al. [14] found that $27 \%$ of CD cases and $22 \%$ of controls carried rs1050152-T. Similarly, we did not find the rs 1050152-T associated with IBD in our Manitoba Caucasian cohort were $49 \%$ of CD patients, $41 \%$ of UC patients, and $43 \%$ of controls carried the risk genotype. These findings support the recently formulated hypothesis that the increased rs1050152-T frequency in IBD cases is related to recent positive selection in the IBD5 locus and that other linked disease-causing variants have hitchhiked to relatively high frequency to determine the risk haplotype [27]. They postulated that a recombination breakpoint exists telomeric of SLC22A4 and that the causative variations are located in the genetic region after that breakpoint, which includes SLC22A5. Our data are consistent with this hypothesis, since we did not see disease associations in SLC22A4. Moreover, haplotype analysis by Waller et al. [14] and Silverberg et al. [11] does indicated that SLC22A4 and SLC22A5 lie in distinct linkage blocks, therefore variations in both genes could independently modify the disease risk. This could explain that SLC22A4 is not involved in disease etiology in our cohort, but in others.

The assumption that SLC22A4 is not involved in disease etiology is also supported by the fact that we did not find the two rarer SLC22A4 functional variations rs $11568510-\mathrm{G}$ and $\mathrm{rs} 11568500-\mathrm{A}$, which abrogate transport activity for the organic cation TEA totally or by $50 \%$, respectively [28]. We had chosen to genotype both rarer SNPs due to their proven impact on the proteins function to query the model of "genetic heterogeneity", which postulates that the genetic contribution to complex traits is determined by the abundance of rare genetic variants of high effect on the disease phenotype [29]. The absence of these detrimental variations also supports the assumption that SLC22A4 variations do not determine the IBD risk in our cohort.

Our findings also differ from reports that both SLC22A4 and SLC22A5 SNPs are within a single genetic linkage block. This might be due to the fact that most studies reported associations for SLC22A4/ SLC22A5 haplotypes rs1050152/rs2631372 [9,24,25] and rs1050152/ rs2631367 [4,14], where the tag-SNPs are located 5' of the SLC22A5 gene, which could still be in a haplotype block with $S L C 22 A 4$. Therefore, we assume that the previously reported eQTL-type $[4,9,24]$ associations for SLC22A5 with IBD are due to SNPs in the SLC22A4 haplotype block. Considering the existing data for linkage breakage between the SLC22A4 and SLC22A5 genes just 5' of SLC22A5 [11,14] we did choose tag-SNPs further located within SLC22A5. This explains why we could achieve distinct and independent associations for our cohort. These two SNPs in SLC22A5 strongly elevated the risk for CD and UC are located in intron 2 (rs17622208) and distal to the 3'UTR (rs11739135), which makes both unlikely candidates to be the functional causal variation, which remain to be identified.

The SLC22A5 gene encodes OCTN2, a carnitine transporter mediating cellular uptake, indicating a role of cellular carnitine deficiency in IBD. This is supported by the observation that intestinal levels of carnitine are reduced by $90 \%$ in Slc $22 a 5^{-/}$knockout mice, which develop spontaneous perforations, micro-abscess, necrotic villi leading to gut atrophy [30]. Neonate Slc22a5 $\%$ mice showed increased enterocytes and lymphocytes apoptosis, which disturbs the epithelial barrier to initiate inflammatory processes [31]. Moreover, oral carnitine supplementation or local carnitine-liposomes administration reduced inflammation and histological damage in the murine trinitrobenzene sulphonic acid induced colitis [32,33]. Supplementation of propionylL-carnitine improved clinical and endoscopic response in UC [34]. Dietary carnitine might therefore be considered to be tested as a supplemental IBD treatment in individuals of the described SLC22A5 genotypes.

\section{References}

1. Rioux JD, Silverberg MS, Daly MJ, Steinhart AH, McLeod RS, et al. (2000) Genomewide search in Canadian families with inflammatory bowel disease reveals two novel susceptibility loci. Am J Hum Genet 66:1863-1870. [Crossref]

2. Rioux JD, Daly MJ, Silverberg MS, Lindblad K, Steinhart H, et al. (2001) Genetic variation in the $5 \mathrm{q} 31$ cytokine gene cluster confers susceptibility to Crohn disease. Nat Genet 29: 223-228. [Crossref]

3. Giallourakis C, Stoll M, Miller K, Hampe J, Lander ES, et al. (2003) IBD5 is a genera risk factor for inflammatory bowel disease: Replication of association with Crohn disease and identification of a novel association with ulcerative colitis. Am J Hum Gene 73: 205-211. [Crossref]

4. Peltekova VD, Wintle RF, Rubin LA, Amos CI, Huang Q, et al. (2004) Functional variants of OCTN cation transporter genes are associated with Crohn disease. Nat Genet 36: 471-475. [Crossref]

5. Hradsky O, Dusatkova P, Lenicek M, Bronsky J, Duricova D, et al. (2011) Two Independent Genetic Factors Responsible for the Associations of the IBD5 Locus with Crohn's Disease in the Czech Population. Inflamm Bowel Dis 17:1523-1529. [Crossref]

6. Martinez A, Martin MD, Mendoza JL, Taxonera C, Diaz-Rubio M, et al. (2006) Association of the organic cation transporter OCTN genes with Crohn's disease in the Spanish population. Eur J Hum Genet 14: 222-226. [Crossref]

7. Newman B, Gu XJ, Wintle R, Cescon D, Yazdanpanah M, et al. (2005) A risk haplotype in the solute carrier family $22 \mathrm{~A} 4 / 22 \mathrm{~A} 5$ gene cluster influences phenotypic expression of Crohn's disease. Gastroenterology 2005;128(2):260-9. [Crossref]

8. Noble CL, Nimmo ER, Drummond H, Ho GT, Tenesa A, Smith L, Anderson N Arnott IDR, Satsangi J. The contribution of OCTN1/2 variants within the IBD5 locus to disease susceptibility and severity in Crohn's disease. Gastroenterology 129:18541864. [Crossref]

9. Repnik K, Potocnik U (2011) Haplotype in the IBD5 region is associated with refractory Crohn's disease in Slovenian patients and modulates expression of the SLC22A5 gene. J Gastroenterolo 46: 1081-1091. [Crossref]

10. Russell RK, Drummond HE, Nimmo ER, Anderson NH, Noble CL, et al. (2006) Analysis of the influence of OCTN1/2 variants within the IBD5 locus on disease susceptibility and growth indices in early onset inflammatory bowel disease. Gut 55: 1114-1123. [Crossref]

11. Silverberg MS, Duerr RH, Brant SR, Bromfield G, Datta LW, et al. (2007) Refined genomic localization and ethnic differences observed for the IBD5 association with Crohn's disease. Eur J Hum Genet 15: 328-335. [Crossref]

12. Torok HP, Glas J, Tonenchi L, Lohse P, Muller-Myhsok B, et al. (2005) Polymorphisms in the DLG5 and OCTN cation transporter genes in Crohn's disease. Gut 54:1421-1427. [Crossref]

13. McGovern DPB, van Heel DA, Negoro K, Ahmad T, Jewell DP, et al. (2003) Further evidence of IBD5/CARD15 (NOD2) epistasis in the susceptibility to ulcerative colitis. Am J Hum Genet 73(6):1465-6. [Crossref]

14. Waller S, Tremelling M, Bredin F, Godfrey L, Howson J, et al. (2006) Evidence for association of OCTN genes and IBD5 with ulcerative colitis. Gut 55:809-814. [Crossref]

15. Vermeire S, Pierik M, Hlavaty T, Claessens G, van Schuerbeeck N, et al. (2005) Association of organic cation transporter risk haplotype with perianal penetrating Crohn's disease but not with susceptibility to IBD. Gastroenterology 129:1845-1853. [Crossref]

16. Li M, Gao X, Guo CC, Wu KC, Zhang X, et al. (2008) OCTN and CARD15 gene polymorphism in Chinese patients with inflammatory bowel disease. World $J$ Gastroenterol 14: 4923-4927. [Crossref]

17. Tosa M, Negoro K, Kinouchi Y, Abe H, Nomura E, et al. (2006) Lack of association between IBD5 and Crohn's disease in Japanese patients demonstrates populationspecific differences in inflammatory bowel disease. Scand J Gastroentero 41: 48-53. [Crossref] 
18. Wang J, Wang X, Yang H, Wu D, Wang L, et al. (2011) Contribution of the IBD5 locus to inflammatory bowel disease: a meta-analysis. Hum Genet 129: 597-609. [Crossref]

19. Xuan C, Zhang BB, Yang T, Deng KF, Li M, et al. (2012) Association between OCTN1/2 gene polymorphisms (1672C-T, 207G-C) and susceptibility of Crohn's disease: a meta-analysis. Int J Colorectal Dis 27:11-19. [Crossref]

20. Clara I, Lix LM, Walker JR, Graff LA, Miller N, et al. (2009) The Manitoba IBD Index: evidence for a new and simple indicator of IBD activity. Am J Gastroenterol 104: 17541763. [Crossref].

21. Satsangi J, Silverberg MS, Vermeire S, Colombel JF (2006) The Montreal classification of inflammatory bowel disease: controversies, consensus, and implications. Gut 55 . 749-753. [Crossref]

22. Cantor MJ, Nickerson P, Bernstein CN (2005) The role of cytokine gene polymorphisms in determining disease susceptibility and phenotype in inflammatory bowel disease. $\mathrm{Am}$ J Gastroenterol 100:1134-1142. [Crossref]

23. Barrett JC, Fry B, Maller J, Daly MJ (2005) Haploview: analysis and visualization of LD and haplotype maps. Bioinformatics 21: 263-265. [Crossref]

24. Kabakchiev B, Silverberg MS (2013) Expression Quantitative Trait Loci Analysis Identifies Associations Between Genotype and Gene Expression in Human Intestine. Gastroenterology 144:1488-1496. [Crossref]

25. Lin ZW, Nelson L, Franke A, Poritz L, Li TY, et al. (2010) OCTN1 variant L503F is associated with familial and sporadic inflammatory bowel disease. J Crohns Colitis 4:132-138. [Crossref]

26. Lakner L, Csongei V, Sarlos P, Jaromi L, Safrany E, et al. (2009) IGR2096a_1 T and IGR2198a $1 \mathrm{C}$ alleles on IBD5 locus of chromosome 5q31 region confer risk for Crohn's disease in Hungarian patients. Int J Colorectal Dis 24: 503-507. [Crossref]
27. Huff CD, Witherspoon DJ, Zhang YH, Gatenbee C, Denson LA, et al. (2012) Crohn's Disease and Genetic Hitchhiking at IBD5. Mol Biol Evol 29: 101-111. [Crossref]

28. Urban TJ, Yang C, Castro RA, Taylor TR, Huang CC, et al. (2007) Functional effects of protein sequence polymorphisms in the organic cation/ergothioneine transporter OCTN1 (SLC22A4). Pharmacogenet Genomics 17: 773-782. [Crossref]

29. Hegele RA (2009) Plasma lipoproteins: genetic influences and clinical implications. Nat Rev Genet 10:109-121. [Crossref]

30. Shekhawat PS, Srinivas SR, Matern D, Bennett MJ, Boriack R, et al. (2007) Spontaneous development of intestinal and colonic atrophy and inflammation in the carnitine-deficient jvs (OCTN2(-/-)) mice. Mol Genet Metab 92: 315-324. [Crossref]

31. Sonne S, Shekhawat PS, Matern D, Ganapathy V, Ignatowicz L (2012) Carnitine Deficiency in OCTN2(-/-) Newborn Mice Leads to a Severe Gut and Immune Phenotype with Widespread Atrophy, Apoptosis and a Pro-Inflammatory Response. Plos One 7: e47729. [Crossref]

32. D'Argenio G, Calvani M, Casamassimi A, Petillo O, Margarucci S, et al. (2006) Experimental colitis: decreased Octn2 and Atb0+expression in rat colonocytes induces carnitine depletion that is reversible by carnitine-loaded liposomes. Faseb J 20: 2544.

33. Fortin G, Yurchenko K, Collette C, Rubio M, Villani AC, et al. (2009) L-carnitine, a diet component and organic cation transporter OCTN ligand, displays immunosuppressive properties and abrogates intestinal inflammation. Clin Exp Immunol 156: 161-171. [Crossref]

34. Mikhailova TL, Sishkova E, Poniewierka E, Zhidkov KP, Bakulin IG, et al. (2011) Randomised clinical trial: the efficacy and safety of propionyl-L-carnitine therapy in patients with ulcerative colitis receiving stable oral treatment. Aliment Pharm Ther 34:1088-1097. [Crossref]

Copyright: (C2018 León AS. This is an open-access article distributed under the terms of the Creative Commons Attribution License, which permits unrestricted use, distribution, and reproduction in any medium, provided the original author and source are credited. 